\title{
When Fortune Smiles onthe Poor: A Storyof Upward Intragenerational Social Mobilityamong Malay FELDA Settlers
}

\author{
Faizah Mohd Fakhruddin, Noor 'AzlanMohd Noor
}

\begin{abstract}
This paper discusses the pattern of social mobility experienced by the first generation Malay FELDA settlers in a FELDA settlement located in Perak. Social mobility patterns are solely gauged by settlers' socio-economic conditions that are compared between the settlers' pre-migration and post migration period to the FELDA settlement. The study involved fieldwork conducted for a period of nine months from December 2014 to August 2015. The study used qualitative method using in-depth interviews and participant observation with thirty settlers. The results of the study show that all of the first generation experienced upward intragenerational social mobility due to their migration to the FELDA settlement. Factors such as better employment opportunities, stable earnings and property ownership offered by FELDA are regarded as important reasons for the settlers' upward social mobility.
\end{abstract}

Keywords: Intragenerational social mobility, FELDA settlement, upward social mobility.

\section{INTRODUCTION}

S Social mobility refers to individuals' dynamism to change their social positions within the social hierarchy that involves either improvement or decline of individuals' strata $[1,2,3]$. In relation to this, since independence in 1957, the Malaysian government has envisioned to create a more developed society in terms of its socio-economic aspects. This could be seen in the implementation of the Malaysian New Economic Policy in 1971 that aimed to eradicate poverty and to restructure society by providing indiscriminated opportunities for all ethnic groups to gain economic growth. In relation to this, the Federal Land Development Authority (FELDA) is seen as a result of the rigorous initiative of the Malaysian second Prime Minister and also the founder of FELDA, Tun Abdul Razak Hussein that started with a RM10 million budget which aimed to manage land development projects and to relocate the poor's settlement. After more than 60 years of its establishment, it is considered as one of the mega agricultural land development projects that succeeded to remedy the economic backwardness situation faced by the nations especially the Malays and enabled them to experience upward social

Revised Manuscript Received on October15, 2019

* Correspondence Author

First Author Name*, School of Human Resource and Psychology,UniversitiTeknologi Malaysia, Johor Bahru, Johor, Malaysia. Email: faizah.mf@utm.my

Second Author Name, Department of Sociology and Anthropology, International Inslamic University Malaysia, Kuala Lumpur, Malaysia. Email: noorazlanmn@iium.edu.my mobility.

This study thus, aims to present a comparison of the Malay FELDA settlers' socio-economic conditions between the pre-migration and post migration periods which determines the intragenerational social mobility patterns they experienced over the years.

\section{LITERATURE REVIEW}

Social mobility can be referred to as the transformation experienced by individuals regarding their social positions within the social hierarchy $[1,2,3]$. There are basically two types of social mobility, horizontal and vertical. The first one refers to an idle state that involves no changes in individuals' social positions and the latter one refers to one's transition in the social strata i.e. either upward (social climbing) or downward (social sinking) [3]. Apart from the patterns of social mobility, there is another aspect of social mobility that is usually studied i.e. the intragenerational and intergenerational mobility. The first refers to only one generation's mobility change that is measured at two different periods of times and the latter refers to comparison made between two generations such as between parents and children [4]. This study for instance, is focusing to the transformation experienced at the intragenerational level.

Since social mobility is considerably related to level of education, occupations and earnings, thus, it also indicates that social mobility is also associated with one's socio-economic status. For instance, many studies highlighted the importance of education could determine one's earnings and thus influence the patterns of social mobility [5,6,7]. In other words, higher individuals' level of education indicated higher level of earnings and lower education level leads to lower earnings.

Further, another pertinent issue that is closely related to social mobility is migration. Many studies have highlighted that migration is essential since it involves the process of moving from one place to another for better prospects for improving their life $[8,9,10]$. Migration is normally done in order to seek for better employment opportunities and the chances to attain other socio-economic benefits such as higher earnings. 


\section{METHODOLOGY}

The study used qualitative method using in-depth interviews and participant observation with thirty settlers resided in a FELDA settlement in Perak. The fieldwork was conducted for a period of nine months beginning from December 2014 to August 2015. 30 first generation settlers were randomly selected as the main source of reference since the study is limited to the intragenerational (one generation) social mobility patterns. Interview schedule related to social mobility questions was used in order to obtain the informants' demographic information as well as the detailed data related to the patterns of social mobility experienced by the said informants.

The issues of consent and confidentiality were obtained and assured through the distribution of information sheet and consent form to all of the informants. MP3 recorder was also used in order to accurately record all the important details uttered by the informants. Frequent visits to all of the informants were made to ensure the reliability and validity of the data gained from the previous interviews. The data was then transcribed in order to make the process of identifying and coding easier. Atlas.ti software was used to systematically code and categorize the themes.

\section{RESEARCH FINDINGS AND DISCUSSION}

The patterns of social mobility experienced by the first generation FELDA settlers can be gauged by comparing their socio-economic conditions in terms of their types of occupation, earnings and assets. In order to clearly see the patterns of social mobility experienced by the first generation settlers, a comparison of their socio-economic situations is made between the periods before they migrated to the FELDA settlement and after they migrated.

\section{A. Pre-migration Period}

1) Occupations

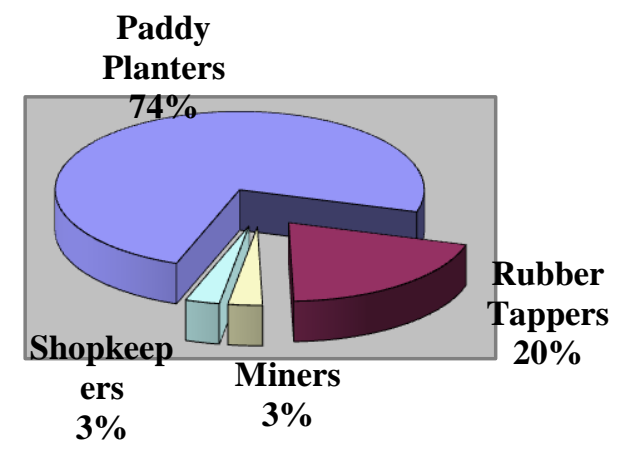

Fig1. Types of Pre-Migration Occupations

Figure 1 above shows that of thirty settlers, $74 \%$ used to work as paddy farmers, $20 \%$ as rubber tappers, $3 \%$ as tin miners and another $3 \%$ as shopkeepers. Based on the data presented in the above figure, it is clear that majority of them were involved in the low-paying jobs during the pre-migration period. There are two responsible factors for this situation to take place. First, it is due to their low level of education because majority of them only had their primary education. This is parallel with findings observed by $[5,6,7]$.
Gao and Smyth for instance, had stated that higher education evidently to increased income per hour i.e. university graduates earned $42 \%$ more than college graduates and the college graduates earned $34 \%$ more than those who had senior middle or polytechnic education [6]. Secondly, it is due to the limited opportunity associated with the location where they lived. This is parallel with previous studies observed by Ahmad HidayahDlt that stated that rural areas usually offered very limited and low-paying jobs [9].

All of the informants described how unfortunate their life was when they used to live in their villages. This includes limited choice of occupations, unstable earnings and inability to property ownership. Since all of the settlers lived in rural areas, the employment opportunity was limited and the only available occupations were 'kerja kampung' (village-based jobs). This "kerja kampung" is mainly associated with agricultural sector such as 'bersawahpadi' (paddy farming) and "menorehgetah" (rubber tapping).

2) Earnings

Further, the "kerja kampung" are also categorized as low-paying jobs and thus, the informants obtained unstable earnings that were insufficient for their family's expenses. This is shown in the narratives of Ibrahim, aged 70 years old related to the said earnings that he gained during the pre-migration period as:

I did everything I could to earn a living when I used to stay in my hometown, Seberang Perak before I migrated to the FELDA settlement. I used to do jobs at the paddy field and chop the woods for my carpentry jobs. However,

I could not earn steady income since my main source of income i.e. the paddy farming activity was only done once in a year. Thus, I ran out of money after the harvesting season ended.

Another informant named Sufian, aged 67 years old also shared similar experience as:

I used to do jobs in the rubber plantation estate in the early 1960s. It was a difficult time for me because I did not earn much from the job I did. I only gained RM6 monthly since I could only worked for 22 days per month at most due to my health condition and other social responsibilities I had. At that time I was very hopeful for the opportunity to occupy job with fixed income.

3) Assets

Besides the issues of limited employment opportunities and unstable earnings, the informants also recounted about the property ownership problem. Majority of them found that it was very difficult and nearly impossible for them to own an asset during the pre-migration period. This is due to the reason of poverty and they could barely cover the cost for their basic necessities such as the kitchen and their children's school expenses. Therefore, even though they really wanted to own a piece of land for housing and plantation purposes, they did not have the ability to do it. This is reflected in the narration of an informant named Anas, 65 years old:

I still remembered how unfortunate my life was during the pre-migration because I used to be hired as a worker at others' plantation and rented a house at the landlord's land. 
As a tenant, I experienced the risk of being evicted or being asked to leave the house at anytime the landlord wanted me to. Therefore, I felt it was extremely important to have an asset i.e. a house in order to ensure my family's welfare in the future.

\section{B. Post-migration Period}

\section{1) Earnings}

The post-migration period indicates the period when all the informants migrated to the FELDA settlement in the early 1970s. Since all of the informants are the settlers, they are all categorized as self-employed individuals who did not earn fixed income and did not receive any retirement benefits such as the Employees Provident Fund (EPF) or the government pension scheme. However, at the early stage of the opening of the settlement, they received RM69 allowance from FELDA because the oil palm trees still did not bear any fruits at that particular time. The allowance was called "wang saradiri" and was considered as a fixed income for them to support their families. Besides "wang saradiri", free groceries such as canned sardines, sweetened creamers and flour were also given to the informants by the government and FELDA during Tun Abdul Razak's era. They could also purchased other grocery items such as rice, cooking oil, vegetables, tea, coffee, salt and sugar at FELDA grocery shops. The purchase was done on a loan basis which was deducted from their "wang saradiri". All of the informants described the said assistance as an utter favour that helped them a lot during that time. This is reflected in the narratives of Amri, aged 71 years old as follows:

He expressed his utmost gratitude for all the assistance given by the government and FELDA to him since the opening of the settlement. He regarded the "wang saradiri" and the free groceries as a very pleasant and accommodating assistance to all the settlers. He was thankful that he migrated to FELDA because such type of "nikmat" (gift) was beyond his wildest dreams and if he still stayed in his village he would not gain such abundant "nikmat".

Besides that, all of the informants also described that there were plenty of job opportunities that could be done at the settlement. Their main job was working as settlers and they also did many types of additional jobs to earn more. There were two categories of settlers were found at the time the fieldwork was conducted. First, the settlers who managed their own plantations and second, those who acted as sleeping partners and let FELDA managed everything about their plantation. It is also interesting to note that most of the informants from each category revealed their earnings. Informants from the first category disclosed that they gained higher earnings compared to the second category because they were able to save some cost and earn more by doing some of the jobs themselves and hiring small number of workers to do the rest. The production of their trees was at optimum level since they were very alert and responsive to the trees' condition from time to time. An informant named Yaaqub, aged 69 years old narrated such situation as follows:

I started to manage my own plantation in the mid 1990s. I replanted 280 oil palm trees on a five acre-land and did all the weeding and fertilizing jobs on my own. The jobs of harvesting and removing tree fronds off the ground on the other hand, were done by three workers that I hired.
My crops could produce up to twelve tonnes a month compared to seven tones for the plantation managed by FELDA. Since the oil palm selling price was RM456 per tonnes, the estimated gross earning ranged between RM4,500 and RM5,000 per month.

On the other hand, settlers in the second category was not involved in any of the plantation matters since FELDA managed everything including hiring workers to do the re-plantation, weeding, fertilizing, cleaning and harvesting jobs. FELDA then deducted all the said costs from the settlers' monthly gross earnings. Therefore, it is comprehensible that their earnings were much lower than the settlers in the first category. This is shown in the narratives of Hud, aged 63 years old:

I normally earned about RM1,000 to RM1,300 net income monthly by letting FELDA managed my plantation. It was considered as pretty low compared to my friends who managed their own plantation.

2) Occupations

Besides doing their main job as settlers, the informants also recounted that they had plenty of chances to find for other additional jobs in various sectors. This includes the agricultural, livestock farming, fishing, aquaculture, service and private sectors and small business enterprises. All of the informants described that it was necessary for them to do such additional jobs so that they could earn more and thus, they were able to do some savings for their future. This is shown in the narratives of Najla, aged 70 years old who did an additional job as a cook as follows:

Besides working as a settler, I used to work as a cook at some stalls that sold Malay ala carte food in the evening. I was also in charge to prepare packed food for a group of foreign contract workers who worked at the nearby construction sites. The wages I earned was sufficient to cover for my family's monthly electrical and water bills as well as for my children's education savings. Iwas very lucky and I would not gain such "nikmat" if I did not migrate to the FELDA settlement.

Similar instances can be found in the narratives of Ayyub, aged 69 years old:

From 1982 to 1990, I used to rear four dairy cows for their milk. The milk was sold within the area of the settlement and the profit from selling it was used to cover for my family's kitchen expenses and for the children's education.

3) Assets

Apart from employment opportunities and stable earnings, all of the informants also expressed their utmost gratitude for the assets they gained by being settlers. It was actually the main objective of the government that intended to eliminate poverty among the Malays by establishing the FELDA project. Every settler who registered for the project was entitled for a 10-acre land for plantation and a quarter acre land for housing lot. Therefore, all of them saw this as an opportunity for them to own assets. This is reflected in the narratives of Daud, aged 63 years old as follows: 
I admitted that my decision to migrate from my hometown, Bagan Serai to the FELDA settlement was the best decision I ever made because the offer of the ten acre of oil palm plantation and a quarter acre of housing lot was very irresistible. I believe that I should not miss such once in a lifetime opportunity to improve my socio-economic status.

From the preceding discussion regarding the patterns of intragenerational social mobility, it is very clear that all of the informants experienced upward social mobility after comparing their socio-economic conditions from two periods i.e. the pre-migration and the post-migration periods.

\section{CONCLUSION}

It is evident from the findings of this study that all of the first generation informants had experienced upward intragenerational social mobility in terms of their socio-economic life. This achievement was possible due to their migration to the FELDA settlement and the government initiative to eradicate the issue of poverty with the establishment of a land scheme called FELDA. They benefitted a lot from it since it offered abundant benefits such as stable income-generated occupation, a variety of additional jobs and most importantly, the opportunity to own personal property i.e. a ten acre of oil palm plantation and a quarter acre of housing lot per settler. This opportunity is fervently regarded as a fortune which they could never have dreamt of because all of them originally came from a poverty-stricken background. Thus, it is evident that the FELDA scheme was found to be successful in uplifting the issue of poverty and thus, enabled the settlers to achieve upward intragenerational social mobility in terms of their socio-economic situation.

\section{REFERENCES}

1. Nor Aini Idris. (2004). Mobilitisosial di kalangangenerasikeduaFelda. Akademika, 64(1). 83-95.

2. Abrahamson, M., Mizruchi, E. H. \& Hornung, C. A. (1976).Stratification and mobility. United States: MacMillan Publishing Co.

3. Sorokin, P. A. (1959). Social and cultural mobility. United States of America: Free Press.

4. Fields, G. (2004). Economic and social mobility really are multifaceted. School of Industrial and Labor Relations, Cornell University, 1-29.

5. Suga, F. (2017). The Returns to Postgraduate Education. Economic and Social Research Institute (ESRI) No.336, 1-31. http://www.esri.go.jp/jp/archive/e_dis/e_dis336/e_dis336.pdf

6. Gao, W., \& Smyth, R. (2015). Education expansion and returns to schooling in urban China, 2001-2010: Evidence from three waves of the China Urban Labor Survey. Journal of the Asia Pacific Economy, 20(2), 178-201.

7. Akgüç, M. (2011). The effects of different stages of education on income across countries. Working paper, Toulouse School of Economics (TSE). 1-28.

8. RosnizaAznie Che Rose, Abdul Rahim Md Nor, Asmah Ahmad, AmriahBuang\&RosmizaMohdZainol. Pemantauankeberkesananpembangunanwilayah Malaysia dalamaspekpenduduktempatan di Iskandar Malaysia. Geografia-Malaysian Journal of Society and Space, 7(5), 40-54

9. Ahmad HidayahDlt. (2007). Faktorekonomi dan keinginanberprestasimasyarakat Padang Lawasbermigrasikekota Medan. Jurnalharmonisosial, 1(3), 122-126.

10. Cooke, M., \& Belanger, D. (2006). Migration theories and First Nations mobility: Towards a systems perspective. Canadian Review of Sociology/Revue canadienne de sociologie, 43(2), 141-164.

\section{AUTHORS PROFILE}

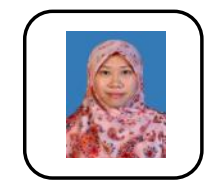

Dr. FaizahMohd Fakhruddin received her Ph.D in Sociology and Anthropology from International Islamic University Malaysia (IIUM) in 2019, Masters Degree in Sociology and Anthropology from IIUM in 2012 and Bachelor Degree in Islamic Revealed Knowledge and Human Sciences from IIUM in 2008.

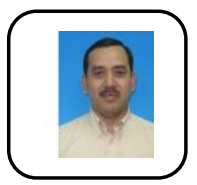

Assoc. Prof. Dr. Noor 'AzlanMohd Noorreceived his $\mathrm{Ph} . \mathrm{D}$ in Social Anthropology (Medical Anthropology) from University of Kent, Masters Degree in Medical Antropologyfrom Universiti Malaya (UM) andBachelor Degree in Sociology and Anthropology from UM. He had published numerous articles such as:

i. Sociocultural determinants of health and illness: a theoretical inquiry. Geografia: Malaysian Journal of Society and Space , 10 (1) pp.49-59 in 2014.

ii. Tourism in Malaysia: problems and prospects in context to socio-cultural and environmental surroundings of the country. South Asian Anthropologist, 14 (2) pp.119-128 in 2014.

iii. Chinese culture and cancer among Malaysian chinese cancer survivors. Asian Social Science , 9 (14) pp.30-41 in 2013.

iv. Health issues among urban Malays. Manusia dan Masyarakat , 14 pp.66-89 in 2005.

He has also published numerous books and book sections such as:

i. Understanding Africa: the stories of culture and change. Partridge Publishing in 2017.

ii. Tourism in Malaysia: an empirical study on socio-economic and environmental impacts. Partridge Singapore. ISBN 978-1-4828-7996-4 in 2016.

iii. Religious tolerance and freedom among Chinese Muslims converts in Malaysia.In: Contemporary issues in Islamic thought IIUM Press, International Islamic University Malaysia . ISBN 978-967-491-008-2 , pp.46-61 in 2018 . 